\title{
|ТИПЫ ОБУЧЕНИЯ
}

\author{
О.В. Щупленков
}

\section{Адаптационные возможности русской национальной школы в эмиграции (на примере Шуменской гимназии в Болгарии (1922-1934 гг.))}

\begin{abstract}
Аннотация. Шуменская гимназия (1922-1934 г2.), передислоцированная в Болгарию из Константинополя, благодаря педагогическому таланту и выдаюшимся организаторским способностям её первого директора А.А. Бейера (1922-1928 гг.), занимала первое место среди всех средних школ Болгарии как по количеству воспитанников, так и по постановке учебно-воспитательной работы. Дело было нелёгкое: здесь обучались разновозрастные юноши, прошедшие сквозь горнило гражданской войны. Несмотря на бедность, скудость питания, жёсткость распорядка дня и проч., годь, проведённые под кровом гимназии, представлялись её выпускникам, испытавщим трудности социализации в инокультурной среде, самыми счастливыми, о чём свидетельствуют их письма, адресованные преподавателям и воспитателям гимназии, отложившиеся в бондах ГА РФ, что значительно расширяет наше знание о пребывании русских эмигрантов в Болгарии. Интегрирующий тип науки проявляется в предмете исследования, что связано с триадой народ - язык - культура.
\end{abstract}

На протяжении многих веков русско-болгарские культурные и языковые контакть являются уникальным примером взаимного обогащения народов. Деятельность гимназии в г. Шумен в 20-30-е гг. ХХ столетия, одной из шести русских гимназий в Болгарии, является свидетельством прямого культурного и языкового взаимодействия между народами Болгарии и России. Во многих отнотениях русские оказались самой привилегированной диаспорой в стране. Такая политика Болгарии предопределила возможность расивета русской эмигрантской культуры. Однако мировая экономическая депрессия кониа 20-30-х гг. ХХ в., охватившая и Болгарию, ухудшает положение русских эмигрантов. Государство, придерживаясь строгой политики национальных приоритетов на рынке труда, приравнивает русских эмигрантов к другим группам иностраниев. Это длилось до сентября 1944 2. и привело многих беженцев к сильному обнишанию. Хотя государство и продолжало помогать им, доля денежной помощи вынужденно сокращается, ликвидируются некоторые эмигрантские учреждения.

С кониа 1930-х г2. начинается новая государственная политика по отношению к русским бежениам. В 1938 г. Лига Наиий принимает положение о том, что русский беженский вопрос «исчерпан», закрывает Международньй Нансеновский офис и рекомендует государствам, принявиим русских эмигрантов, начать политику, на повсеместную натурализацию русских. На этом заканчиваются благоприятнье отношения $\kappa$ русской эмиграции, русские приравнень к другим иностраниам. Новая политика, наряду с репрессиями против русских беженцев во время 2-й мировой войны, отмечает начало процесса ассимиляции русских эмигрантов.

Ключевье слова: Бейер, Болгария, культура, культуроведение, образование, русская эмиграция, соииализаиия в изгнании, Шуменская гимназия, язык, языкознание.

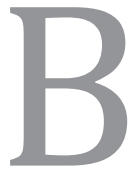

рамках данной статьи мы остановимся более подробно на историческом срезе начала XX в. и попытаемся выяснить характер и значимость русско-болгарских лингвокультурных контактов. Однако прежде следует осветить историко-культурные предпосылки и факторы, которые легли в основу русскоболгарского лингвокультурного взаимодействия в указанный период и традиции преподавания русского языка в Болгарии ${ }^{1}$.

\footnotetext{
${ }^{1}$ Щупленков О.В. Адаптационные возможности русской эмиграции «первой волны» // Исторические, философские, политические и юридические науки, культурология и искусствоведение. Вопросы теории и практики. Тамбов, 2010. № 2. C. 115-116.
} 


\section{Типы обучения}

Формирование условий кульминационного развития лингвокультурного взаимодействия в конце XIX века уходит своими корнями во вторую половину XVIII века, когда наблюдается активизация наступательной (против Османской империи) политики России, послужившая, наряду с осложнением внутренней ситуации в Болгарии, толчком к культурно-просветительскому движению как первому этапу процесса Возрождения в Болгарии. Болгарский народ получает материальную и моральную поддержку со стороны России. B XVIII веке в болгарской литературе наблюдается прославление России ${ }^{2}$. Болгарские авторы несут глубокую убежденность и веру болгарского народа, находящегося под гнетом османских завоевателей в то, что русский и болгарский народы - братья и в то, что Россия принесет долгожданное освобождение Болгарии. Об этом говорит П. Хилендарски в своем произведении «История славяноболгарская» (1762), подчеркивая, что язык его книги является, собственно, переработкой русского народного языка. Исследователи подчеркивают, что в этот период «политическая ориентация южных славян на Россию, сознание своего племенного и культурного единства с восточными славянами требовали создания и сохранения общей с ними культурной платформы, восприятия и выработки единого языка»³. Процесс Возрождения в Болгарии начинается борьбой за национальный литературный язык как орудие культуры народных масс. Болгарские просветители смотрели на русский язык не только как на средство усвоения идейных и художественных ценностей русской культуры, но и как на материал обогащения болгарского языка на уровне лексики, как на инструмент для культурной его обработки и усовершенствования ${ }^{4}$. Наряду с русской печатной и рукописной литературой, распространяемой в Болгарии и являющейся достоянием грамотного населения, в домашнее богослужение, а, следо-

\footnotetext{
${ }^{2}$ Ангелов Б. Ст. Съвременници на Паисий. С.: Изд-во на БАН, 1963. Кн. 1. ГАРФ. Ф. Р-6502. Союз русских писателей и журналистов в Югославии. Оп. 1. Д. 307; Павлова Р. Болгарско-русские и русско-болгарские языковые связи. София: Народна просвета, 1979. С. 169.

${ }^{3}$ Толстой Н.И. История и структура славянских литературных языков. М.: Наука, 1988. С. 92.

${ }^{4}$ Попов К. Из историята на българския книжовен език. София: Изд-во на БАН, 1985. С. 152.
}

вательно, и в устную речь «вторгается» русский вариант старославянского языка.

В XVIII веке происходит своеобразная «трансфузия древнеславянского языка» - древнеболгарский язык, пройдя определенную обработку на Руси, возвращается в Болгарию. Процесс болгарского языкового строительства под влиянием родственного развитого языка проходит в очень короткий срок: начавшись в XVIII веке, он завершается к концу XIX века 5 .

B XIX веке, кроме непрекращающихся «книжных» контактов, все чаще русско-болгарские связи осуществляются в ходе прямого русско-болгарского общения: соприкосновение русских и славян во время наполеоновских войн ${ }^{6}$ и русско-болгарские контакты во время русско-турецких войн (1806-1912 гг.). Они послужили толчком к пробуждению в России научного интереса к истории, этнографии, языку Болгарии, к развитию славяноведения. Деятельность русских ученых-славистов (И. Востоков, К. Калайдович, И. Срезневский, В. Григорович и др.), создание кафедры славянской литературы и истории в Московском университете (1835) способствовали укреплению русско-болгарских связей. По мнению Р. Павловой, «именно русские слависты первыми вернули из забвения имена многих древнеболгарских писателей, показали богатство и значимость древнеболгарской книжности» ${ }^{7}$.

Пристальное внимание к Балканам, в частности к Болгарии, политическая зависимость которой давно вызывала негодование русского народа, выливается в России в мощное общественное движение. Помогая православным церквям, школам, финансируя обучение болгар в русских учебных заведениях, оказывая материальную поддержку славянским народам, Славянские комитеты способствуют пробуждению народов и росту национально-освободительного движения на Балканах. В 60-70 годы XIX века в России получают образование 300 болгар, составивших впос-

\footnotetext{
${ }_{5}^{5}$ Ангелов. Б. Ст. Из старата българска, руска и сръбска литература. Т. І. София, 1958; Т. II. София, 1967. С. 212-213.

${ }^{6}$ Дьяконова И.А. Художественное своеобразие романов Гайто Газданова: Автореф. дисс. ... канд. филол. наук. Северодвинск, 2003.

7 Павлова Р. Болгарско-русские и русско-болгарские языковые связи. София: Народна просвета, 1979. С. 169.
} 


\section{Педагогика и просвещение 4(12) • 2013}

ледствии ядро болгарской интеллигенции ${ }^{8}$. С их помощью болгарский народ знакомится с лучшими достижениями русской и мировой культуры, на основе которых происходит возрождение и становление болгарской духовности, строительство национального языка9.

В середине XIX века, в период бурного роста национальной борьбы, подъема общественной и литературной жизни, в Болгарии под влиянием русского языка осуществляется формирование лексической, терминологической и фразеологической систем болгарского языка. Введение светского образования в Болгарии требовало канонизации языковой концепции, новой учебной литературы ${ }^{10}$. С 1846 года в школах вводится преподавание русского языка как учебного предмета, хотя и до этого времени учащихся знакомили с русской церковной и учебной литературой ${ }^{11}$. Русский язык становится «ключом к науке»- ведь в болгарских школах учились по русским учебникам ${ }^{12}$. Дидактическим целям и задачам общекультурного характера было подчинено формирование терминологической системы болгарского языка. Большая заслуга в этом принадлежит Н. Герову, опиравшемуся при создании терминов на народный язык или воспринимающему их из русского языка ${ }^{13}$. С именем $\mathrm{H}$. Герова связывается и начатая лексикографическая практика в Болгарии. Русско-болгарский и болгарско-русский словари Н. Герова издаются в России. Словарь болгарского языка содержит толкование

\footnotetext{
${ }^{8}$ Гацак В.М. Фольклор и молдавско-русско-украинские исторические связи. М.: Наука, 1975.

9 Челышев Е.П. Российская эмиграция: 1920-30-е годы: история и современность. М.: Граф-Пресс, 2002; Шавельский Г.И. Русская школа в Болгарии // Педагогика Российского Зарубежья. М.: Ин-т психологии РАН, 1996. С. 381; Шуменски вести. № 17. 15 април, 1922. С. 2.

${ }^{10}$ Соковнин П.Н. Данные опыта русских учебных заведений в Болгарии по некоторым вопросам эмигрантской школы // Бюллетень Педагогического Бюро. Прага. № 7. 1925. С. $32-33$.

${ }_{11}$ Андрейчин Л. Из историята на нашето езиково строителство. София: Народна просвета, 1986. С. 7.

12 Бабов К. Найден Геров и его вклад в болгарскую русистику // Болгарская русистика. №1. София, 1988. С. 14; Бабов К. Руско-българските езикови контакти и въпросът за типологията на русизмите в българския език // Славянска филология. Т. 15. София, 1978. С. 40.

${ }^{13}$ Строители и ревнители на родния език. Пантеон / Съставили: Л. Андрейчин и В. Попова. София: Наука и изкуство, 1982. С. 174.
}

слов на русском языке, а болгарские фразеологизмы сопровождаются русскими эквивалентами, что, несомненно, способствует в определенной степени ассимиляции в болгарском языке русской и международной фразеологии ${ }^{14}$.

Освобождение Болгарии от турецкой зависимости осуществляется в ходе русско-турецкой войны (1877-1878), во время которой балканские народы сражались плечом к плечу с русскими солдатами ${ }^{15}$. Эти события запечатлены в произведениях болгарского фольклора, мемуарной и художественной литературы русского и болгарского народов. В Болгарии установлено более 440 памятников, прославляющих мужество и храбрость русских солдат. Кровопролитные события военных лет явились яркой демонстрацией

\footnotetext{
${ }^{14}$ Киржаева В.П. Преподавание русского языка в условиях эмиграции // Образование и педагогическая мысль российского зарубежья, 20-50-е гг. XX в.: Тез. докл. и сообщ. второй всерос. науч. конф. «Образование и пед. Мысль рос. зарубежья, 20-50-е гг. ХХ в.» (Саранск, 16-18 окт. 1997 г.) / Под ред. Е.Г. Осовского. Саранск: МГПИ, 1997. С. 74; Кьосева Ц. Руската емиграция в България. София: Междунар. център по проблемите на малцинствата и културните взаимодействия, 2002. С. 88, 92; Строители и ревнители на родния език. Пантеон / Съставили: Л. Андрейчин и В. Попова. София: Наука и изкуство, 1982. С. 174; Толстой Н.И. История и структура славянских литературных языков. М.: Наука, 1988. С. 92; Щупленков О.В. Диалектика воспитания в эмиграции первой волны // Перспективы науки. Тамбов, 2010. № 7. С. 84-87; Щупленков О.В., Щупленков Н.О. Идеи солидаризма в концепции построения гражданского общества в России // NB: Проблемы общества и политики. 2013. № 8. С. 72-137; Щупленков О.В. Императивы национальной идеи // NB: Философские исследования. 2013. № 2. С. 122-164; Щупленков О.В. История молодежного движения в России в современном исследовательском поле // Исторические, философские, политические и юридические науки, культурология и искусствоведение. Вопросы теории и практики. Тамбов, 2012. № 1-2. С. 211-215; Щупленков О.В. Источники финансирования русской школы в эмиграции 1920-1930-х годов // В мире научных открытий. Красноярск, 2011. Т. 15. № 3. С. 146-150; Щупленков О.В., Щупленков Н.О. Национально-культурная идентичность в контексте философской традиции диалога культур // NB: Философские исследования. 2013. № 10. С. 183-244.

${ }^{15}$ Маринов М., Узунов Х., Караиванов А., Даков Т. Рускотурската освободителна война 1877-1878 гг. София: Държ. изд-во «Народна просвета», 1977.; Хевролина В.М. Руско-турската война 1877-1878 гг. и прогресивна Русия // Българското Възраждане и Русия / Ред. колегия Д. Косев и др. София: Наука и изкуство, 1981. С. 35-57.
} 


\section{Типы обучения}

культурной и духовной близости народов России и Болгарии.

После освобождения Болгарии русское присутствие в стране продолжается в течение ряда лет. Временное русское управление налаживает административную и военную систему, здравоохранение, просвещение и т.д. Основные посты во временном управлении занимают русские офицеры и гражданские чиновники. Начатое еще до Освобождения Болгарии преподавание русского языка становится в стране обязательным. Библиотеки и читальни были заполнены русскими книгами. Из сферы образования русский язык перемещается и в другие сферы жизни Болгарии. Начинается влияние русской науки во всех областях знания, в болгарский литературный язык проникает много русских научных терминов ${ }^{16}$.

Прямое русско-болгарское лингвокультурное взаимодействие после освобождения Болгарии поддерживается также потоком эмигрантов из России, преследуемых царским правительством, многие из которых сыграли немаловажную роль в жизни страны. В Болгарию, где так явно ощущался дефицит квалифицированных специалистов, идет поток русских эмигрантов. Русская эмигрантская волна в Болгарию усиливается в 20-е годы XX века, сразу после революционных потрясений в России. Среди эмигрантов были высоко образованные представители различных сословий ${ }^{17}$, не понимающие и не принимающие изменений в России и надеявшиеся найти приют в братской славянской стране, в которой еще были сильны чувства благодарности русскому народу за свое освобождение. Указанная эмиграция получила название «белой эмиграции». Исследователи классифицируют эмиграционные потоки по соци-

\footnotetext{
${ }^{16}$ Мечев К. Българска фолклорна прослава на Русия от края на XVIII век // Балкански културни връзки през Средновековието. София: Изд-во на БАН, 1982. С. 182-190; Петров А. Материалы по истории русской школы за рубежом // Русская школа за рубежом. № 9. Прага, 1924. С. 92-118; Петрушева Л. Болгария и российская эмиграция (Государственный архив Российской Федерации) // Болгария и российская эмиграция 1920-1945. Каталог выставки. М., 2007. С. 12-13; Стрельцов А.А. Гимназии русского зарубежья // Вопросы образования. 2006. № 2. С. 248-264; Цонев Б. История на българския език. Т. 2. София, 1934. C. $311-370$.

${ }^{17}$ Раев М. Россия за рубежом. История культуры русской эмиграции 1919-1939 / Пер. с англ. М.: Прогресс, Академия, 1994. С. 15.
}

альной принадлежности эмигрантов, вопросам их приема и устройства и выделяют четыре волны в Болгарии. В первую волну эмиграции (середина 1918-1919 г.) входили представители русской аристократии и некоторые дипломаты Российской империи, их устройством и размещением занимались общественные организации, некоторые сочувствующие России политические партии и Болгарская православная церковь; вторая волна эмиграции (январь - апрель 1920 г.) состояла из военных Добровольческой армии, их устройством занимались как официальные власти, так и ведущие эмигрантские структуры с центром в Париже и дипломатический представитель правительства А.И. Деникина в Софии А.М. Петряев; третья (основная) волна эмиграции (конец ноября 1920-1921 г.) состояла из военных армии П.Н. Врангеля и части гражданского населения из Крыма, принятые в Болгарии по условиям специального договора; с четвертой волной эмиграции в Болгарию прибыли военные части и гражданское население из Константинополя, принятые в страну под давлением Лиги Наций. История русских беженцев тесно переплетается с историей Болгарии ${ }^{18}$.

По сведениям Русского Красного креста, к 1 февраля 1922 г. в Болгарии находятся 29993 русских беженцев, из которых 25248 мужчин, 3061 женщин и 1684 детей (Русское дело 1922). А по данным советской организации Союз возвращения на Родину (Совнарод), на 25 марта 1923 года количество русских беженцев составляло 25000-30000 человек, из которых 18628 человек были солдатами и офицерами Русской армии под командованием П.Н. Врангеля, переброшенными из военных лагерей Турции ${ }^{19}$. Остальная часть около 7500 человек были гражданскими ${ }^{20}$. В более поздних источниках указывается, что в 1921-1922 гг. количество русских беженцев доходит до 45000 человек ${ }^{21}$. Известно, что в период с 1922-1923 годов вследствие давления Советского правительства и репатриации на Родину вернулись более 11

\footnotetext{
${ }^{18}$ Кабанова Е.В. Школа и учительство русской эмигрантской диаспоры в Европе: 1919-1930 гг. Дисс. ... канд. пед. наук. М., 1998.

${ }^{19}$ ЦДАРБ. Ф. 176 К. Оп. 4. А. е. 2734; ЦДАРБ. Ф. 2734. Л. 7.

${ }^{20}$ Там же. Л 29, 31, 33.

${ }^{21}$ Кьосева Ц. Руската емиграция в България. София: Междунар. център по проблемите на малцинствата и културните взаимодействия, 2002. С. 88.
} 


\section{Педагогика и просвещение 4(12) • 2013}

тысяч русских беженцев. В любом случае можно утверждать, что так называемая белая эмиграция составила более 30 тысяч человек, из них 7 тысяч были представителями интеллигенции. Русская эмиграция отличается многосословностью и высокой образованностью и вносит значительный вклад в развитие Болгарии, в том числе болгарской науки, культуры и образования. В то же время ей принадлежит огромная заслуга в сохранении и приумножении русской культуры.

Русским эмигрантам помогает выжить в новой обстановке объединение в разного рода организации (на социальной и профессиональной основе). В общей сложности в период с 1920 по 1944 гг. в Болгарии зарегистрировано более ста русских эмигрантских организаций. Среди них Общество единения русских в Болгарии, просуществовавшее с 1920 по 1924 год. Наряду с решением проблем выживания, ставились цели сохранения русской культуры, религии и языка. Организациями издаются 85 эмигрантских газет и журналов ${ }^{22}$.

Вопросами беженцев занимается специально созданная правительственная организация Комитет по делам русских беженцев. Несмотря на то, что русские беженцы считались иностранцами, по действующим законам в Болгарии они приравнивались к национальным меньшинствам ${ }^{23}$.

Среди русских эмигрантов было очень много детей. Правительство А. Стамболийского отпускает 2000000 левов на прием 3000-7000 русских детей, находящихся в Константинополе (Стамбуле) ${ }^{24}$. В феврале 1922 г. Министерский совет разрешает приезд в Болгарию еще 160 русских детей из Египта и 45 родителей некоторых из них ${ }^{25}$.

\footnotetext{
22 Димитров Э. Русская эмиграция в Шумене // Русское зарубежье в Болгарии. История и современность. София: Русский академический союз в Болгарии, 2009. С. 126.

${ }^{23}$ Щупленков О.В. Национальные особенности политического активизма российской молодежи в эмиграции 1920-х-1930-х годов // Исторические, философские, политические и юридические науки, культурология и искусствоведение. Вопросы теории и практики. Тамбов, 2011. № 7-3. C. $220-222$.

${ }^{24}$ Воспоминания В.Б. Семихата-Сосинского. Архив Ф. Хадоновой; Спасов Л. България и СССР 1919-1944 г.: Политико-дипломатически отношения. Велико Търново: Фабер. 2008. С. 82; Он же. Врангеловата армия в България 1919-1923. София: Унив. изд. Св. Климент Охридски. 1999. C. 82 .

${ }^{25}$ Даскалов Д. Бялата емиграция в България. София:
}

Затем в Болгарию переводятся дети из гимназий в Константинополе и Египте. В общей сложности в период 1921-1922 г. Болгария дает кров 1800 детям, а к 1924 году их число достигает 2500-3000 чел., из них $84 \%$ получают возможность посещать русские эмигрантские школы ${ }^{26}$.

В связи с необходимостью обучения и воспитания детей-эмигрантов, в Болгарии начинают работать дошкольные, школьные и внешкольные учреждения, в том числе шесть русских гимназий в городах София, Варна, Шумен, Пловдив, Долна Оряховица и Пещера. В общей сложности к лету 1922 года в Болгарии действуют 19 учебных заведений ${ }^{27}$. Учебный и воспитательный процесс в них был нацелен на сохранение русского языка и русской культуры, а также национальной идентичности эмигрантского населения, что способствует выживанию в инокультурной среде, но в то же время затрудняет вхождение и адаптацию в инокультуре. Кроме того, в Болгарии организуются курсы по изучению русского языка, истории, географии России, создаются русские культурнонациональные центры и организации ${ }^{28}$.

Унив. изд. Св. Климент Охридски. 1997. С. 139; Кьосева Ц. Руската емиграция в България. София: Междунар. център по проблемите на малцинствата и културните взаимодействия. 2002. С. 88.

${ }^{26}$ Горяинов А.Н. Культурно-просветительных организации русских эмигрантов в Болгарии (до начала $30-$ х годов XX века) // Славяноведение. 1994. № 4. С. 29; Горяинов А.Н. Русская эмигрантская школа в Болгарии (1920-е гг.) // Педагогика. 1995. № 1. С. 78; Петрушева Л. Русская эмигрантская школа в Европе // Славяноведение. 2009. № 1. С. 29.

${ }^{27}$ Петрушева Л. Отцы и дети русской эмиграции // Дети русской эмиграции. М.: Терра, 1997. С. 13-15.

${ }^{28}$ Бирман М.А., Горяинов А.Н. Российские интеллектуалы-эмигранты в Болгарии 1920-1930 годов // Новая и новейшая история. 2002. № 11. С. 173-193; Васильева С.Н. Особенности развития содержания русской школы в условиях эмиграции // Ист.-пед. основания стратегии развития отечественного образования / Под ред. З.И. Равкина. М.: ИТГТ, МИО РАО, 1994; Она же. Проблемы развития русской школы в условиях эмиграции (1918-1930) // Современные проблемы истории образования и педагогической науки: В 3-х т. / Под ред. 3.И. Равкина. Т. 3. М.: ИТПИМИО, 1994. С. 20-26; Газданов Г. Собр. соч.: В 3-х т. М.: Согласие, 1996-1999; Даскалов Д. Професионален и културен профил на бялата емиграция в България // Бялата емиграция в България: Материали от науч. конф., София, 23-24 септ. 1999 г. / Ред. кол. Г. Марков и др. София: ИК Гутенберг, 2001. С. 71-78; Кьосева Ц. Руската емиграция и българската държава (20-те - 50-те години на XX 


\section{Типы обучения}

В деле создания русских учебных заведений в Болгарии огромная роль принадлежит различным эмигрантским общественным организациям, русских педагогам, земско-городским объединениям, а также неоспоримой финансовой и юридической помощи болгарского государства. В частности, болгарское правительство ежемесячно субсидирует гимназии в размере 500 тыс., а затем 570 тыс. левов ${ }^{29}$. С июля 1920 г. до 1 января 1931 г. почти половина всех средств на финансирование русского учебного дела в Болгарии были выделены из болгарского государственного бюджета ${ }^{30}$. Впоследствии в 30-е годы учащиеся русских гимназий переориентируются в болгарские школы ${ }^{31}$.

Проблемы русской школы, ее роль в жизни русской диаспоры и Болгарии освещаются в многочисленных работах русских и болгарских исследователей (Э. Димитрова, Ц. Кьосева, Г. Рупчева, И. Петров, Н.А. Родионова, П.Е. Ковалевский, Е.Е. Седова и др.). В современных исследованиях используются различные подходы и затрагиваются аспекты дидактического, исторического, культурологического характера ${ }^{32}$. Нас интересует лингво-

в) // Бялата емиграция в Българии. Материали от научна кнференция София, 23 и 24 сентября 1999 г. София: Институт по история Българска академия на науките, 2001. С. 51-70; Щупленков О.В. Общественно-политическая самобытность русской эмиграции 1920-1930-х годов // Исторические, философские, политические и юридические науки, культурология и искусствоведение. Вопросы теории и практики. Тамбов, 2011. № 5-4. С. 219-221; Щупленков О.В. Патриотическое воспитание в военном образовании Российского Зарубежья в контексте современного исторического образования школьников // Преподавание истории в школе. 2007. № 10. С. 68.

${ }^{29}$ Централен държавен архив на Република България. София. Ф. 166К. Оп. 3. А. е. 68.

${ }^{30}$ Кёсева Ц. Болгария и русская эмиграция: 1920-1950е годы. М.: Библиотека - фонд «Русское Зарубежье», Русский путь, 2008. С. 66.

${ }^{31}$ Ангелов Б. Ст. Съвременници на Паисий. С.: Изд-во на БАН, 1963. Кн. 1.

${ }^{32}$ Ковалевский П.Е. Зарубежная Россия: история и культурно-просветительная работа русского зарубежья за полвека. Париж: Librairie des cinq continents, 1971. С. 42; Кьосева Ц. Руската емиграция в България. София: Международен център по проблемите на малцинствата и културните взаимодействия, 2002; Петров А. Александър Петрович Дехтерев. // Бялата емиграция в България. София.: ИК Гутенберг, 2001. С. 328-353; Рупчева Г. Гайто Газданов - ученик в руската гимназия в Шумен // Неуморният търсач: Сборник / Ред. П. Панайотов. Шумен: Аксиос, 2005. С. 39; Седова культурная значимость русской школы в аспекте культурного и языкового взаимодействия русского и болгарского народов. Этот своеобразный вид проявления непосредственных, прямых лингвокультурных контактов изучается на примере Шуменской гимназии, которая является одной из наиболее значимых в Болгарии (после Софийской и Варненской $)^{33}$.

К моменту прибытия в Болгарию русских эмигрантов страна представляла собой печальное зрелище. Потерпев поражение в Первой мировой войне, униженная и ограбленная Нейсским договором 1919 года, Болгария продолжала платить репарации французам и англичанам, однако, тем не менее, приняла около 35 тыс. русских беженцев, которые остались в стране на постоянное жительство и создали сеть русских школ с целью воспитания подрастающего в эмиграции поколения в русле отечественной культуры.

Под эгидой правительства Болгарии был создан специальный орган - Комитет русских беженцев, который занимался проблемами социальной адаптации русских эмигрантов.

Всех детей школьного возраста в первой половине 20-х годов в Болгарии было 2000, не считая 800 студентов $^{34}$.

Были открыты гимназии в Варне (125 чел.), Тырново (275 чел. обоего пола), Шумене (250), Пещере (160) и Софии (134 чел.) ${ }^{35}$. При гимназиях были интернаты. Основная масса учащихся жила в интернатах гимназии, даже если родители жили в городе, поскольку зачастую бытовые условия жизни учащихся в их семьях складывались неблагоприятно для их морального и духовного развития. Педагоги русской школы считали, что условия интерната позволят лучше адаптировать детей к новой жизни и избежать денационализации ${ }^{36}$.

Е.Е. Пути национального воспитания в образовательной системе российской эмиграции 20-30-х гг. ХХ в. // БЕРЕГА: Информационно аналитический сборник о русском зарубежье. Вып. 9. СПб., 2008. С. 30-39.

${ }^{33}$ Бочарова 3.С. Российское зарубежье 1920-1930-х гг. как феномен отечественной истории. М.: АИРО-XXI, 2011.

${ }^{34}$ Государственный архив Российской Федерации (ГАРФ) ГАРФ. Ф. Р-5766. Уполномоченный Всероссийского союза городов в Болгарии. Оп. 1. Д. 176.

${ }^{35}$ Кабанова Е.В. Школа и учительство русской эмигрантской диаспоры в Европе: 1919-1930 гг. Дисс. ... канд. пед. наук. М., 1998. С. 66.

${ }^{36}$ Стоянова Е.В. Устаревшие фразеологические единицы 


\section{Педагогика и просвещение 4(12) • 2013}

В Шумене и Шуменском регионе к 1923 г. проживают 1565 человек ${ }^{37}$, это второе по численности (после Софии) эмигрантское поселение в Болгарии. Учениками Шуменской гимназии становятся представители русской колонии в Шуменском регионе, в их числе 252 воспитанника из Константинополя, 200 воспитанников старших классов расформированного Донского кадетского корпуса из Египта, а затем из расформированной русской гимназии из Тырново Сеймен (г. Симеоновград) ${ }^{38}$. Фактически, перевод в Шумен в 1922 году большей части Константинопольской гимназии и послужил основой формирования Русской гимназии в Шумене ${ }^{39}$.

Русская гимназия занимает площадь 19,5 га и располагается на северо-западной окраине Шумена. Вокруг огромного дома, выделенного для нужд образования, был сад и огород, которые служат хорошим подспорьем в жизни обитателей гимназии. Во дворе в одном из зданий бывшей больницы устраивается церковь при гимназии, которая освящается в ноябре 1922 г. Церковные службы часто посещают жители Шумена.

Возраст гимназистов был различен. Его средний показатель, например, в 1924 г. составляет 16,7 лет ${ }^{40}$. При гимназии существует мужской и женский интернат. Педагоги русской школы придерживаются мнения, что условия интерната позволят детям лучше адаптироваться к новым условиям жизни и избежать денационализации ${ }^{41}$. Это обусловливало определенную законсервированность русского языка и культуры, способствуя их сохранению и превращая гимназию в островок России на территории Болгарии. И в то же время ограничивало возможности широких контактов ${ }^{42}$.

русского языка и их болгарские эквиваленты. Дисс. ... канд. филол. наук. М., 2002; Сухачева В.А. Проблемы образования детей и юношества в Российском Зарубежье (1920-1940 гг.) // Вестник МГПУ. Серия «Педагогика и психология». 2008. № 3 (26). C. 86-96.

${ }^{37}$ ЦДАРБ. Ф. 2734. Л. 7.

${ }^{38}$ Държавен архив - Шумен (ДАШ). Ф 57ОК. Оп. 1. А. е. 1.

${ }^{39}$ Русское дело. № 113. София, 1922. 22 апреля; Русское дело. № 87. София,1922. 19 марта.

${ }^{40}$ Государственный архив Российской Федерации (ГАРФ) ГАРФ. Ф. Р-5766. Уполномоченный Всероссийского союза городов в Болгарии. Оп. 1. Д. 176. Л 56.

${ }^{41}$ Шаклеин В.М. Лингвокультурная ситуация и исследование текста. М.: Общество любителей русской словесности, 1997.

${ }^{42}$ ГАРФ. Ф. Р- 5976. А.П. Дехтерев. Оп. 1. Д. 24.
Кроме того, оценивая основные задачи гимназии в эмиграции, воспитатель интерната Шуменской гимназии А.П. Дехтерев писал о том, что русская школа в эмиграции выступает в роли не только охранительницы национального лица русских детей, а спасительницы «русских детей от грозящей им в эмиграции физической и моральной гибели» ${ }^{43}$.

В гимназии работает высококвалифицированный преподавательский состав. С переводом Константинопольской гимназии в Шумен приехали 30 учителей и воспитателей ${ }^{44}$. Из 24 преподавателей гимназии 13 были с университетским образованием ${ }^{45}$. Например, биологию преподавал П.К. Дылев, врач гимназии. До 1928 года директором гимназии был А.А. Бейер, русский дворянин, полковник царской армии, библиотекарь и инспектор Константиновского артиллерийского училища, в годы гражданской войны служил в Добровольческой армии ${ }^{46}$.

Программа обучения в Шуменской гимназии в основном соответствует программе дореволюционной русской классической гимназии. Кроме того, изучаются предметы реального училища. Блок предметов под названием «Россика» (куда входили русский язык и литература, география и история России и др.) способствует формированию и развитию у гимназистов русской ментальности ${ }^{47}$. Русские школы в Болгарии обязаны были согласовывать свои программы с требованиями болгарских государственных школ. Так, Министерство Народного Просвещения Болгарии требовало изучения болгарского языка, истории, географии и литературы в объеме местных школ, введения в учебные планы предметов естественной истории, химии, политической экономии и рисования ${ }^{48}$.

\footnotetext{
${ }^{43}$ Русская школа за рубежом. Книга 24. Прага: Издание Объединения Земских и Городских Деятелей в Чехословакии, 1927. С. 702-706.

${ }^{44}$ Шуменски вести. № 17. 15 април, 1922. С.2; Шуменски вести. № 15. 24 март, 1923.

${ }^{45}$ ДАШ. Ф.57ОК. Оп. 11. А. е. 3.

${ }^{46}$ Русская армия в Первой мировой войне (http://www. grwar.ru/persons/persons.html?id=4343, дата обращения 17.07.2013)

47 Диенеш JI. Гайто Газданов: Жизнь и творчество. Владикавказ: Изд-во Сев.-Осет. ин-та гуманитарных исслед., 1995.

${ }^{48}$ Соковнин П.Н. Данные опыта русских учебных заведений в Болгарии по некоторым вопросам эмигрантской школы // Бюллетень Педагогического Бюро. Прага, 1925. №
} 


\section{Типы обучения}

Архивные документы свидетельствуют об установившейся тесной связи гимназии с различными общественными организациями Шумена, а также и жителями города. Не раз в шуменской печати публикуются слова благодарности Директора гимназии шуменцам, которые содействовали не только финансово (например, город ежегодно давал 30 тысяч левов для покупки сукна на костюмы гимназистам ${ }^{49}$, но и помогали кто, чем мог русским детям, оказавшимся в сложной ситуации ${ }^{50}$.

Шуменцы были желанными гостями на различных мероприятиях, организуемых в гимназии. Достоинством и отличительной чертой гимназии является широко развитая самодеятельность учащихся и внеклассная деятельность: кружки и собрания.

Вначале Шуменская гимназия содержалась Всероссийским Союзом Городов и ЗемскоГородским Комитетом. По мере истощения средств Земгора большую часть средств обеспечивало болгарское правительство, без поддержки которого существование гимназии было бы невозможным. «Мы были для болгар «братушки», спасшие Болгарию от 500-летнего турецкого ига», - писал Глеб Левшин, выпускник Шуменской гимназии. (Воспоминания Г. Левшина).

Русские эмигранты расценивали эту поддержку как жертвенный акт человеколюбия болгарского народа. Со сменой кабинета радикального деятеля Стамболийского и приходом «умеренного» правительства Цанкова отношение к гимназии даже улучшилось. 14 августа 1923 г. новое правительство приняло на себя содержание тех школ, которые ранее были исключительно на содержании Земгора ${ }^{51}$. Средства на содержание

\footnotetext{
7. C. $32-33$.

${ }^{49}$ Генов Ц. Славянските комитети в Русия и българското освободително дело (1858-1878). Велико Търново: Изд-во на отечествения фронт, ДП «Д. Найденов», 1986. С. 104; Шавельский Г.И. Русская школа в Болгарии // Труды 5-го съезда русских академических организаций за границей. 4.1. Приложение 2. София, 1932. С. 473.

${ }^{50}$ Шуменски вести. № 63. 10 ноември, 1923; Шуменски вести. № 10. 9 февруари, 1924; Шуменски вести. № 37.23 май, 1924; Шуменски вести. № 31. 23 април, 1927;Шуменски вести. № 65.5 септември, 1928.

${ }^{51}$ Киржаева В.П. Преподавание русского языка в условиях эмиграции // Образование и педагогическая мысль российского зарубежья, 20-50-е гг. ХХ в.: Тез. докл. и сообщ. второй всерос. науч. конф. «Образование и пед. Мысль рос.
}

гимназии поступали от Комиссии Г.Д. Цветинова и от проф. Д. Уиттмора. Г. Цветинов - член Комитета русских беженцев, зав. Отдела Министерства иностранных дел Болгарии. Американский проф. Д. Уиттмор, уверовавший в великое будущее русской культуры, духовная мощь которой базировалась на признании приоритета нематериальных ценностей, учредил стипендии для русских студентов. В духовности русской культуры он видел её уникальность, которая могла погибнуть в результате тяжёлых испытаний, выпавших на долю России, когда русский человек был поставлен в условия физического выживания.

Вынужденный прагматизм и утилитаризм русских в Советской России, по его мнению, подорвал уникальность русской культуры, возродить которую должна эмигрантская молодёжь. С этой целью он ежегодно предоставлял стипендии лучшим выпускникам гимназий, при условии, что они, получив образование, вернутся в Россию.

Болгарское правительство ежемесячно субсидировало гимназии в размере 570 тыс. лев. (4 тыс. дол. $)^{52}$ или 12 тыс. левов в год на содержание каждого русского школьника ${ }^{53}$, при этом большинство родителей могли оплачивать лишь 7-10 часть расходов по содержанию и обучению детей в школе и интернате. Окончившие гимназию имели право поступления в высшие учебные заведения Болгарии и других европейских стран.

Руководство образовательным и воспитательным процессом в эмиграции осуществляло созданное в Праге в 1924 г. общерусское Педагогическое бюро по делам средней и низшей русской школы за границей, которое возглавил проф. В.В. Зеньковский (товарищ председателя - А.В. Жекулина), и Объединение русских учительских организаций за границей (ОРУОЗ), председателем которого была избрана А.В. Жекулина. Русским учебным делом в Болгарии ведал Уполномоченный Всероссийского Союза городов А.В. Арцишевский.

зарубежья, 20-50-е гг. ХХ в.» (Саранск, 16-18 окт. 1997 г.) / Под ред. Е.Г. Осовского. Саранск: МГПИ. 1997. С. 74.

${ }_{52}$ Васильева С.Н. Проблемы развития русской школы в условиях эмиграции (1918-1930) // Современные проблемы истории образования и педагогической науки: В 3-х т. / Под ред. 3.И. Равкина. Т. 3. М.: ИТПИМИО, 1994. С. 20-26.

${ }^{53}$ Шавельский Г.И. Русская школа в Болгарии // Педагогика Российского Зарубежья. М.: Ин-т психологии, 1996. С. 381. 


\section{Педагогика и просвещение 4(12) • 2013}

Шуменская гимназия, передислоцированная в Болгарию из Константинополя в 1922 г., занимала первое место среди всех средних школ Болгарии, как по количеству воспитанников, так и по постановке учебно-воспитательной работы.

В отчете Земско-городского комитета говорилось, что «несмотря на материальные невзгоды, лишения и недостатки, Шуменская гимназия представляет собой явление самое отрадное и даже выдающееся» ${ }^{54}$. Её уникальность состояла в составе её учеников, подавляющее большинство которых уже имело как минимум среднее образование ${ }^{55}$. Гимназия обеспечивала им кров над головой и возможность выправить аттестаты для поступления в высшие учебные заведения.

Выпускник Шуменской гимназии Гайто Газданов, в будущем - известный писатель, так охарактеризовал социальный состав учащихся: «...это были бывшие солдаты, офицеры, матросы, спекулянты, только что вырвавшиеся из ада гражданской войны»... ${ }^{56}$.

Газданов Г.И. (1903, Петербург - 1971, Мюнхен), происходил из семьи серединной российской интеллигенции, учился в провинции. В 1919 г., не закончив гимназии, вступил солдатом в Добровольческую армию. Курсировал по югу России на пулемётной платформе бронепоезда. В 1920 г. с войсками ген. Врангеля навсегда покидает Россию. Впереди - Галлиполийские лагеря, учёба в русской гимназии в Константинополе, переезд в г. Шумен (Болгария) в связи с переводом туда гимназии. После окончания гимназии в 1923 г. - разгрузка барж в Сен-Дени, тяжкая работа на автомобильном заводе. С сер. 20-х годов для Газданова открывается писательская стезя. В 1928-1952 гг. работал ночным таксистом ${ }^{57}$.

Участник французского Сопротивления. Ещё более резко о своих однокашниках отзывался бывший шуменец, Вл. Семихат-Сосинский: «Мы были

\footnotetext{
54 Достян И.С. Българите в руската литература и периодичен печат през първите десетилетия на XIX век // Българското Възраждане и Русия / Ред. колегия Д. Косев и др. София: Наука и изкуство, 1981. С. 194.

55 Щербатов А., Криворучкина-Щербатова Л. Право на прошлое. М.: Срет. Монастырь, 2005. С. 113.

${ }^{56}$ Воспоминания выпускников Шуменской гимназии. Архив Н.Г. Пчелинцевой.

57 Газданов Г. Собр. соч. в 5-и т. М.: Эллис Лак, 2009. Т. 1. С. 759-760; T.2. С. 325-335.
}

настоящие бандиты, и только благодаря опытности, такту и энергии Анатолия Аполлоновича Бейера - очень строгого, но и очень справедливого «немчуры» - директора, в Шуменской гимназии поддерживались дисциплина и шли нормальные занятия и общественная жизнь» ${ }^{58}$.

Владими р Брониславович Сосинский (Владимир Бронислав Рейнгольд Брониславович Сосинский-Семихат) (1900-1987). В 1918 году был призван в Белую армию, воевал, был ранен в грудь навылет, награжден орденом Николая Чудотворца лично генералом Врангелем. В 1920 году покинул Крым и оказался в Константинополе.

В 1922 году закончил гимназию в г. Шумен (Болгария). В 1924 году переезжает из Берлина в Париж, работает жестянщиком на заводе «Рено», меняет множество других профессий и активно печатается в русских журналах. Некоторые критики в обзорах молодой эмигрантской литературы называли его среди наиболее многообещающих прозаиков наряду с Владимиром Сириным. Женился на дочери лидера партии эсеров М.В. Чернова. Участник французского Сопротивления. В 1960 г. вернулся в Советский Союз.

Благодаря умелому воспитательному воздействию педагогического коллектива закончившие гимназию становились добропорядочными гражданами, патриотами своего покинутого отечества. Более тесные и доверительные отношения учащихся эмигрантской школы с педагогами и воспитателями, чем это было на родине, и дух товарищества, царивший в школе, создавали «благоприятную атмосферу для воспитательного воздействия на разношёрстную великовозрастную молодёжь, настолько поломанную жизнью, что многим из молодых людей скорее нужны были исправительные учреждения, а не гимназическая скамья» 59

Подранки, «подстарки» (так 3. Гиппиус называла состарившееся раньше времени молодое поколение эмигрантов, испившее горечь братоубийственной войны) примерным поведением не отличались, и А.А. Бейер, который был директором гимназии до отъезда в Америку в 1928 г., чтобы

\footnotetext{
${ }^{58}$ Водовозов В. Русские в Болгарии // Всеславянский календарь. Praha: Пламя, 1926. С. 78.

${ }^{59}$ Димитров Э. Русская эмиграция в Шумене // Русское зарубежье в Болгарии. История и современность. София: Русский академический союз в Болгарии, 2009. С. 64.
} 


\section{Типы обучения}

обеспечить нормальное функционирование гимназии, поспешил освободиться от великовозрастных гимназистов, выдав им документы о среднем образовании. Таким образом, в 1923 г. было два выпуска: первый выпуск состоялся в январе 1923 г. - 57 чел, в сентябре 1923 г. - 43 ученика ${ }^{60}$.

Бейер Анатолий Аполлонович (10 ноября 1875 - 6 апреля 1938) выпускник Михайловского Артиллерийского училища, генерал-лейтенант артиллерии, участник гражданской войны, директор гимназии в Шумене (1923-1927 гг.), уехал в Парагвай, где жил его приятель, друг президента этой страны. В Буэнос-Айресе служил в газовой компании. Вел большую культурную работу среди русских эмигрантов, основал кружок «Наука и техника», с чтением докладов, затем переименованный в кружок «Наука и искусство». Участвовал в войне с Боливией, в результате которой Парагвай присоединил огромную боливийскую территорию Гран-Чако. Бывший директор получил звание героя Парагвая, и ему установлен там памятник. Скончался в 1940-х годах ${ }^{61}$.

Школа в эмиграции имела большее значение для её воспитанников, чем в России. Многим она заменила не только семью, но и стала частичкой их родины. Выпускники гимназии связи с ней не порывали. Переписка с выпускниками бережно сохранялась, письма переписывались в дневник шуменской гимназии. Дневник читали, и связь между членами разбросанной по всему свету шуменской семьи упрочивалась ещё больше. В. Ридель, представитель Земгора в Берлине, писал: «Эти дневники у меня берут на прочтение здешние шуменцы.

А я всё мечтаю, что кто-нибудь с чётким художественным дарованием, вроде короленковского, когда-нибудь использует этот ценнейший психологический материал из быта русской гимназии на чужбине» ${ }^{62}$. Подобным дарованием обладал выпускник гимназии Г. Газданов, посвятивший Шуменской гимназии рассказ «На острове» (директор гимназии А. Бейер изображён автором

\footnotetext{
${ }^{60}$ Достян И.С. Българите в руската литература и периодичен печат през първите десетилетия на XIX век // Българското Възраждане и Русия / Ред. колегия Д. Косев и др. София: Наука и изкуство, 1981. С. 65.

${ }^{61}$ Щербатов А., Криворучкина-Щербатова Л. Право на прошлое. М.: Срет. Монастырь, 2005. С. 113.

${ }^{62}$ ГАРФ. Ф. Р-5766. Оп. 1. Д. 49. Л. 1-2.
}

под именем Мейера), а также некролог «Анатолий Аполлонович Бейер».

«Я хотел бы написать об Анатолии Аполлоновиче самые верные, самые лучшие слова, которые я знаю», - пишет Г. Газданов. — «Я хочу надеяться, что он знал всегда, до последних дней своей жизни, что наша благодарность ему и наша преданность его памяти неизменны» ${ }^{63}$.

Анатолия Аполлоновича Бейера любили все. Подобно большинству преподавателей гимназии, он был профессиональным военным, генералом артиллерии, воевавшим в Добровольческой армии. Он никогда не прибегал ни к каким наказаниям, даже никогда не повышал голоса, но его авторитет был неоспорим.

Бейер обладал удивительным педагогическим даром, «и у него не могло быть и не было плохих учеников. У него нельзя было не учиться - не только потому, что он делал свой предмет интересным (он преподавал физику), но ещё и оттого, что это было неловко по отношению к нему лично» ${ }^{64}$. Более 50 лет спустя после окончания гимназии её выпускники, вспоминая юные годы в «шуменской семье», по-прежнему верили, что директор гимназии, которого многие из них в письмах называли «папа», их всех любил, и они платили ему тем же.

Однако переписка Бейера свидетельствует о непрочности его положения. Дело в том, что преподавательский состав гимназии - участники Белого движения, генералы, служившие в армии Деникина и Врангеля - Корниловцы, Алексеевцы, Дроздовцы, Марковцы, - были монархистами, которых кадетское руководство Земгора не жаловало. Бейер успешно руководил гимназией в течение 7 лет, и все эти годы, страдая от нестабильности своего положения, пытался найти работу в Израиле, думал о возвращении в Россию или обосноваться в Южной Америке, что он и сделал в 1928 г.

Выпускники гимназии были обеспокоены судьбой гимназии, письма А. Бейера о «поскрипывании» гимназии встревожили их, хотя оптимизм молодости одерживал верх: «...Не верится, что гимназию закроют. Ан. Ап. такой энергичный, и столько раз он уже отстаивал гимназию. Выкрутится и на этот раз. Мы так верим в Ан. Ап., что сомнения

\footnotetext{
${ }^{63}$ Воспоминания выпускников Шуменской гимназии. Архив Н.Г. Пчелинцевой. Т. 1. С. 760.

${ }^{64}$ Там же. С. 759.
} 


\section{Педагогика и просвещение 4(12) • 2013}

быть не может - пока он директор, гимназия умереть не может» ${ }^{65}$.

После отъезда А.А. Бейера в Америку в 1928 г. при сменивших его на посту директора А.Н.Кореневе (до его смерти в 1929 г.) и Н.А. Парманине (до закрытия гимназии в 1934 г.) гимназия медленно приходила в упадок: утрачивались традиции, заложенные Бейером, а вместе с ними уходила в прошлое та особая атмосфера гимназии, которая позволяла её выпускникам с гордостью носить имя шуменцев и ощущать свою принадлежность шуменскому братству.

Гимназия находилась за городом, ей было предоставлено здание бывшей дивизионной больницы 1-ой Преславской дивизии в г. Шумене, построенное турками ещё в 1739 г. Это было учебное заведение закрытого типа, с неукоснительно соблюдавшимся распорядком дня и проживанием учащихся в интернатах.

Освещение было керосиновое, а отопления вовсе не было, пока ученики сами не устроили глиняных печей. Здание было ветхим: крыша, полы, двери, окна требовали капитального ремонта, но на те небольшие средства, которые отпускались на ремонт, гимназия не в состоянии была отремонтировать здание. Полы проваливались, бывали случаи провала учеников с повреждением ног. Крыши протекали. Во время дождя во многих помещениях лилась вода с потолков. С мокрых потолков отваливалась штукатурка. Подобная обстановка не способствовала подъёму духа у прошедшей сквозь ужасы гражданской войны и эвакуации молодёжи ${ }^{66}$.

Число учащихся гимназии (в разные годы от 210 до 250 чел.) примерно на 40\% превышало соответствующее количество площадей, которое считалось нормальным или допустимым. Кровати стояли по 2 вплотную друг к другу, между 2 кроватями - проход, необходимый для того, только чтобы подойти к своей кровати ${ }^{67}$.

Русская школа в зарубежье строилась на основе трудового принципа. Выпускников готовили к предстоящим трудностям, к тому, что большинству из них придётся заниматься тяжёлым физическим трудом. Все текущие потребности внутренней жизни обслуживались самими учащимися гимназии при самом небольшом содействии служащих. Умения и навыки, полученные в гимназии, были особенно необходимы в условиях эмигрантской жизни, создавая наиболее прочную, а нередко и единственную основу для обеспечения заработка.

В Болгарии действовал закон, устанавливающий так называемые «трудовые недели», когда все граждане, в том числе и учащиеся, привлекались к обязательному исполнению различных работ на пользу государства. Учащиеся старших классов привлекались к заготовке дров на зиму. Обычно эта трудовая неделя открывала новый учебный год. Это была работа в лесу, на природе, но это был тяжёлый физический труд, и в памяти выпускников отложились самые разнородные впечатления: «С песнями строем шли домой, и каким вкусным был для нас в эти дни ужин, когда собирались мы все в нашей уютной столовой» (Воспоминания выпускников). Другому участнику трудовой недели запомнилось, что «рубка леса была самая тяжёлая, изнурительная работа. Участок леса, который давали болгары, обыкновенно был на склоне горы, а дорога была наверху. Срубленные деревья скатывались вниз, и их нужно было выносить на дорогу и грузить на телеги. «Еда была такая „вкусная“, что ты её в рот, а она обратно» (Воспоминания выпускников). Голодно было всегда. Наряды на кухне в помощь повару любили больше всего: можно было хоть раз, но досыта поесть.

Меню состояло главным образом из капусты в разных видах, фасоли и тыквенной каши. В дневнике гимназии много внимания уделяется содержанию праздничного стола. Еда представляла ценность, достойную подробного описания, что свидетельствует о недостаточном питании: «На Пасху каждый учащийся получил «по четверти небольшого кулича, по 2 яйца, по кусочку колбасы, сала, брынзы, по пирожку и по чашке сладкого чая с вином. Обед - зелёные щи с яйцом и котлеты с гарниром. Какао с куличом. Вечером каждый получил по яйцу и по 50 г колбасы» ${ }^{68}$. В обычные дни вдоволь не ели даже хлеба, в качестве поощрения участникам гимназического оркестра

\footnotetext{
${ }^{65}$ ГАРФ. Ф. Р- 6277. Н.Д. Ридигер. Оп. 1. Д. 6.

${ }^{66}$ ДАШ. Ф. 57ОК. Оп. 1. А.е. 62.

${ }^{67}$ ГАРФ. Ф.Р-5976. Оп. 1. Д. 64.
}

${ }^{68}$ ГАРФ. Ф. Р- 5766. Оп. 1. Д. 49. Л. 134 


\section{Типы обучения}

выдавалась трижды в неделю добавочная порция хлеба $(100 г)^{69}$.

Починка и шитьё одежды и белья производилась самими учащимися. Одеждой и обувью дорожили. Не у всех детей имелось даже по 2 комплекта нижнего белья. У $30 \%$ - по одному комплекту, так что когда это бельё стиралось, ребёнок должен был находиться в кровати под одеялом. Обувью были обеспечены не более 25\% всех детей. Даже зимой вынуждены были носить сандалии и туфли. «Недостаточно напитанный, плохо одетый, иногда босой или в деревенских сандалиях, летом почти сплошь без обуви, зимой - трясущийся от холода из-за отсутствия тёплой одежды и поэтому несущийся по коридорам и дворам гимназии не иначе как бегом» ${ }^{70},-$ таким предстаёт перед нами ученик гимназии в докладе А.А. Бейера на Совещании представителей русских учебных заведений в Болгарии в ноябре 1924 г.

Пережитые страдания не могли не отразиться в поведении подростков. В соответствии с русской традиционной культурой система воспитания в гимназии была репрессивной. Иной она и не могла быть, если учитывать контингент учащихся.

Судя по записям гимназического журнала, взыскания и наказания были не редки. Арест в дальней запертой комнате сроком от 1 до 3 дней с утра до вечера (карцер) считался самой суровой мерой воспитательного воздействия.

Использование карцера как средства наказания и воспитания противоречило болгарскому просветительскому законодательству и послужило одним из поводов к закрытию гимназии в 1934 г. Серьёзную озабоченность руководства гимназии вызывало пьянство, поскольку подрывало её престиж и авторитет, а от этого зависело расположение болгар и та помощь, которую они так щедро оказывали русским беженцам ${ }^{71}$.

Несмотря на голодный паёк, холод зимой, жару летом, клопов, съедающих заживо, тракийскую малярию и лазарет, всегда полный больными, среди которых всё больше и больше появлялось туберкулёзных, оптимизм, свойственный молодости,

\footnotetext{
${ }^{69}$ ГАРФ. Ф. Р- 5976. Оп. 1. Д. 4. Л. 26.

${ }^{70}$ ГАРФ. Ф. Р- 6089. Оп. 1. Д. 10. Л. 144.

71 Родионова Н.А. Проблема воспитания детей в эмиграции: труды и дни Шуменской гимназии (1922-1934) // Исторический журнал. Научные исследования. 2011. № 5. C.60-70.
}

не иссякал и поддерживал уверенность в том, что «молодость, благие порывы, присущее молодости стремление к добру и истине сумеют побороть все эти невзгоды», все трудности будут оправданы радостью служения в недалёком будущем Великой, свободной России...

Однако жизнь не оправдала благих ожиданий. Сбылись «горькие, полные жгучей правды слова», сказанные преподавателем гимназии на выпускном акте, о том, что по окончании гимназии выпускников «ожидает грязь, мерзость, злоба людская, пошлость - то, что составляет оборотную сторону жизни» ${ }^{72}$ «Оборотная сторона жизни» открылась во всей своей неприглядности: «Ваня не успевает отдыхать после работы, похудел, постарел, - описывает свой унылый быт жена выпускника Шуменской гимназии Коринского-Коркина. - ...У нас новостей никаких нет, жизнь здесь пошлая, узкая, женщины занимаются проституцией, а мужчины пьянствуют - вот и вся жизнь Перника» ${ }^{73}$.

Столкновение с чудовищной прозой жизни заставляло забыть и скудные помещения интернатов, и недостаток белья, одежды, обуви, питания, и необходимость подчиняться строгим правилам гимназии. Гимназию вспоминали с любовью, считая её своей родной семьёй: «Находясь вдали от гимназии, я тем более тоскую по ней, тоскую, что утратил то, что заменяло для меня семью» ${ }^{74},-$ пишет выпускник Л. Фельдау. «Есть у меня острое желание спуститься на лодке по Дунаю до Рущука и пешком дойти до Шумена», - мечтает выпускник гимназии С. Щедрович в письме к воспитателю Н.Д. Ридигер ${ }^{75}$.

Н.Д. Ридигер (1870 г. р.) - закончила в 1887 г. Закавказский девичий институт и в 1905 г. - сестринские курсы при Вятской Земской больнице. Вдова. В гимназии выполняла обязанности воспитателя и сестры милосердия. Вместе с А.А. Бейером в 1928 г. уехала в Парагвай. Дальнейшая судьба неизвестна.

Эмигранты, «люди цивилизационного пограничья» ${ }^{76}$, лишившись своего пространства, русской

\footnotetext{
${ }^{72}$ ГАРФ. Ф. Р-6089. Бейер. Оп. 1. Д. 16. Л. 51.

${ }^{73}$ ГАРФ. Ф. Р-5766. Оп. 1. Д. 32. Л. 72.

${ }^{74}$ ГАРФ. Ф. Р-6277. Н.Д. Ридигер. Оп. 1. Д. 6. Л. 30.

${ }^{75}$ ГАРФ. Ф. Р-5766. Оп. 1. Д. 49. Л. 71.

${ }^{76}$ Земсков В.Б. Писатели цивилизационного «промежутка»: Газданов, Набоков и другие // Гайто Газданов и «незамеченное поколение»: писатель на пересечении традиций и куль-
} 


\section{Педагогика и просвещение 4(12) • 2013}

культурной среды, особенно остро ощутили культурный шок при непосредственном столкновении с действительностью.

Под кровом гимназии ощущали себя как в родной семье, тем сильнее мучили воспоминания и мечтали о милом, грязном, пыльном, но безумно дорогом Шумене» ${ }^{77}$. Ностальгия усугублялась пониманием своей чужеродности и ненужности в инокультурной среде. Г. Газданов точно определил мироощущение русских эмигрантов: «Мы живём, окружённые иностранцами ${ }^{78}$. Русские эмигранты, выпав из своей национальной ячейки, не прикрепились к другим, они маргинальны: «Не знаю, что нужно пережить или может быть раньше ещё создать себе особую психику, чтобы иметь возможность жить полной жизнью живя в чужой стране. Меня чувство отчуждённости, полного одиночества никогда не покидает» ${ }^{79}$.

Блистательный Париж, вожделенный Берлин и даже благоволившая русским Прага не особенно стремились открыть объятия русским нищим эмигрантам.

Письма выпускников свидетельствуют об отчаянном положении тех, кто после окончания гимназии оказался без какой-либо социальной поддержки. Многие, надеясь на получение стипендии в рамках Русской акции президента Масарика, отправились в Чехию, однако Болгария «оказалась наиболее терпеливой в деле помощи русской учащейся молодёжи». Стипендию в Чехии получить было очень трудно, да и она далеко не обеспечивала жизнь: «Денег нет, и в прекрасной Чехии голодают так, как никто не голодал здесь в Болгарии. Не имея еды (по 3 и более дней) и живя в нетопленой комнате, они (речь идёт о выпускниках Шуменской гимназии. - О.Щ.) лежат целыми днями в постели, чтобы не замёрзнуть» ${ }^{80}$. Получить стипендии в Чехии удавалось далеко не всем желающим: если в 1923 г. всех прибывших сразу приняли на «иждивение», в 1924 г. — только медалистов и только на частичное «иждивение» - 300 крон в месяц. Эти стипендии были даны

тур. М.: ИНИОН РАН, 2005. С. 14

${ }^{77}$ ГАРФ. Ф. Р-6277. Оп. 1. Д. 3. Л. 15; ГАРФ. Ф. Р-6277. Оп.

1. Д. 12.

${ }^{78}$ ГАРФ. Ф. Р-6089. ОП. 1. Д. 10. Л. 12.

${ }^{79}$ ГАРФ. Ф. Р-6089. Бейер. Оп. 1. Д. 14. Л. 18.

${ }^{80}$ ГАРФ. Ф. Р-5976. Оп. 1. Д. 4. Л. 76. после того, как в Праге, выбросившись из окна студенческого общежития, покончил счёты с жизнью один студент - иждивенец. «Что будет в будущем году, скольким иждивенцам придётся прыгать с 5 этажа, одному Богу известно» $81,-$ пишет выпускник Шуменской гимназии, пытавшийся получить стипендию Масарика для продолжения образования в Брно.

Русская акция Масарика не могла продолжаться долго. С каждым годом таяли надежды на падение большевистского режима и сокращалось количество средств в помощь русским эмигрантам. Безысходность провоцировала мысли о самоубийстве: «Положение в Чехии ужасное... Из 75 млн в этом году дали только 23 млн. - сумму, полагающуюся русским студентам. Честно говорю, милая Нина Дмитриевна, (Ридигер, воспитатель гимназии. - О.Щ.), не раз приходила мысль броситься куда-нибудь под автомобиль» ${ }^{82},-$ пишет выпускница гимназии Н. Кротова. Положение женщины - студентки было в сотни раз тяжелее, чем мужчины. Женщинам предоставляли стипендии крайне неохотно, присваивая им третью, низшую категорию приоритетности при распределении стипендий. Женщин - студенток было мало. На землемерном отделении инженерно-строительном факультета университета в Брно учились только 2 девушки - выпускницы Шуменской гимназии сироты сёстры Н. и Л. Кротовы. На их долю досталась полная чаша страданий: «Очень плохо с лёгкими, температура, питание - тарелка борща и кусок хлеба в день, иногда и того нет» ${ }^{83}$. Однако следуя совету А.А. Бейера, на судьбу не жаловались, об их отчаянном положении знали только шуменцы, всячески старавшиеся помогать сёстрам и очень за них порадовались, когда их прилежание к учёбе было награждено стипендией чешского правительства ${ }^{84}$.

Наиболее обездоленной среди всех абитуриентов была парижская часть шуменцев. Многие выпускники, надеясь заработать денег на продолжение образования, нашли работу на угольных шахтах во Франции. Изнурительный труд по 16 часов в сутки и экономия на питании подрывали

\footnotetext{
${ }^{81}$ ГАРФ. Ф. Р-5766. Оп. 1. Д. 49. Л. 71.

${ }^{82}$ ГАРФ. Ф. Р-6277. Н.Д. Ридигер. Оп. 1. Д. 6. Л. 7-71.

${ }^{83}$ Там же.

${ }^{84}$ Там же. Л. 90.
} 


\section{Типы обучения}

здоровье, у многих обострился застарелый со времён гражданской войны, туберкулёз. Снижение социального статуса переживалось тяжело, «для бедных шахтёров», как они себя называли, любые знаки внимания, особенно со стороны директора гимназии, вселяли радость и надежду: «Вчера получили письмо от Анатолия Апполоновича, и радости нашей не было конца! Сам дорогой Ан. Ап. вспомнил нас и написал! Знаете, какую роль играет иногда моральная поддержка?

Чувствуешь, что ты не просто хам, а человек. Для нас, бедных шахтёров, такое внимание особенно дорого» ${ }^{85}$.

В ностальгических письмах выпускников не упоминаются трудности гимназического быта, которые приходилось переживать и преодолевать, представляло ценность то ощущение семьи, общности судьбы, защищённости, которое согревало душу и заставляло тосковать по утраченному раю: «Вот ещё только 8 дней, как мы уехали из Шумена, но уже такая скука и тоска, тоска по утраченному Шумену. Я никогда не думал, что так тяжело будет расставаться с ним, а теперь чувствую, что уехав, потерял что-то дорогое. Каждую минуту вспоминаем Шумен и говорим только о нём» ${ }^{86}$. «Я так тоскую о Шумене, Болгарии. Я так люблю её, что для меня это вторая Родина. А гимназия - моя семья» ${ }^{87}$. Считая гимназию родным домом, выпускники на каникулы приезжали в Шумен, где их принимали, кормили бесплатно, несмотря на скудный бюджет гимназии. Когда было особенно тяжело, скрывались от безжалостного мира за стенами гимназии: после операции по приглашению воспитательницы гимназии Н.Д. Ридигер выпускник Н. Коринский - Коркин восстанавливая силы в Шумене, Б. Духопельников, заболев малярией, просил отправить его в Шумен ${ }^{88}$. Однако не все могли позволить себе роскошь побывать в Шумене: у многих не было денег не только на дорогу, но даже на почтовую открытку. «Хотелось мне в Шумен до боли, - пишет Борис Духопельников Н.Д. Ридигер, обращаясь к ней «милая, дорогая мамочка». - «Однако на праздники не приехал, стеснялся выделяться своим диким видом - в

\footnotetext{
85 Там же. Л. 48.

${ }^{86}$ ГАРФ. Ф. Р-5976. Оп. 1. Д. 4. Л. 193.

${ }^{87}$ ГАРФ. Ф. Р-6277. Н.Д. Ридигер. Оп. 1. Д. 6. Л. 7-71.

${ }^{88}$ Там же. Л. 17.
}

барашковой папахе и истёртых штанах и куртке как огородное пугало» ${ }^{89}$.

Больше всего писем выпускников обращено к Н.Д. Ридигер. Её слова утешения «вселяли надежду и окрыляли душу». «В наш «милый век» столько чисто материнской ласки, забот и участия я ещё не встречал ни от кого, кроме как от Вас» ${ }^{90},-$ пишет Николай Коринский-Коркин. «Если я буду когдалибо Вам нужен, то помните, что для Вас я на всё готов», - пишет из Безансона выпускник гимназии Илья Телал. Н.Д. Ридигер для него - воплощение идеала женщины-матери, «у которой в самые трудные моменты для каждого найдётся и ласка, и необходимое ободрение, которые так дороги нашему брату. [...] Вы являетесь в моих глазах тем совершенством, которое только живёт для других и ничего не хочет для себя. [...] Вы заменили и заменяете многим мать, а потому также дороги, как и мать» ${ }^{91}$. Многие мечтали побывать в милой уютной «жалейке» - комнате Нины Дмитриевны, где некогда слушали наставления «мамочки» (так называли Н.Д. Ридигер - О.Щ.), «черпали силы для жизненной борьбы, научались жизни» ${ }^{92}$.

«Целую Вас крепко, крепко, в глаза, чтобы Вас никто не любил больше меня» ${ }^{93}-$ заканчивает письмо к Н.Д. Ридигер Наташа Шевырёва.

Трудно измерить любовь ученика к своему воспитателю, но Н.Д. Ридигер, как и директора гимназии А.А. Бейера любили все. Они заменяли родителей, гимназия - семью, и учащиеся чувствовали себя защищёнными. Не случайно, многие выражали желание уехать вместе с ними в Америку: «Не писала часто - денег нет, - оправдывается выпускница гимназии Н. Кротова. - Милая моя мамочка! Будет ли когда время, когда я буду целовать Вашу руку? Мне кажется, когда увижу Вас, то умру. Родная! Милая! Не знаю, любите ли Вы меня, но я люблю Вас... Милая! Родная! Оказалось, что кроме гимназии, а гимназия - это Вы и Анатолий Аполлонович, родных нет. Милая Нина Дмитриевна! Если Вы поедете в Америку или куда-нибудь, то всегда - всегда буду с Вами,

\footnotetext{
${ }^{89}$ ГАРФ. Ф. Р-5766. Оп. 1. Д. 32. Л. 33.

${ }^{90}$ ГАРФ. Ф. Р-6089. Бейер. Оп. 1. Д. 16. Л. 17 об. 18.

${ }^{91}$ ГАРФ. Ф. Р-6277. Н.Д. Ридигер. Оп. 1. Д. 6. Л. 92.

${ }^{92}$ ГАРФ. Ф. Р-6277. ОП. 1. Д. 3. Л. 37.

${ }^{93}$ ГАРФ. Ф. Р-6277. Н.Д. Ридигер. Оп. 1. Д. 6. Л. 60.
} 


\section{Педагогика и просвещение 4(12) • 2013}

постараюсь дать Вам отдохнуть, ведь у Вас дочери нет!» ${ }^{94}$.

Выпускники гимназии считали себя братьями, даже если в гимназии не были знакомы. И хотя попытки создать шуменское землячество не удались, однако шуменское братство состоялось: 13 стипендиатов-шуменцев 4-го выпуска отчисляли ежемесячно по 50 левов для обеспечения товарищеской стипендии И. Туроверову ${ }^{95}$. Индивидуалист-одиночка Г. Газданов, проверивший в Париже на собственном опыте прочность Шуменских связей, в письме А. Бейеру свидетельствует: «Если бы не мои Шуменские друзья, я бы, вероятно, не доехал бы до Парижа и был бы лишён удовольствия писать Вам сейчас письмо» ${ }^{96}$. Г. Газданову оказывал помощь в первый самый трудный период его пребывания в Париже бывший врач гимназии П.К. Дылёв. Уехав в Конго, он в течение многих лет отчислял средства для обеспечения стипендий нескольким выпускникам Шуменской гимназии ${ }^{97}$.

К сожалению, большинству надежд выпускников Шуменской гимназии не суждено было сбыться: «нужда и горе оказались такой же плохой и бесплодной наукой, какой был для них опыт гражданской войны и долгой жизни за границей» ${ }^{98}$. Лишь наиболее удачливые получили высшее образование, остальным пришлось влачить беспросветное существование, добывая уголь на шахтах Перника, нанимаясь к болгарским крестьянам на сбор винограда, работая на постройке дорог, на рубке леса в Балканских или Родопских горах, на фермах по разведению шелковичных червей, однако, светлые воспоминания о гимназических годах впоследствии многим помогали жить.
Русская гимназия в Шумене просуществовала до 1934 года ${ }^{99}$ и смогла подготовить несколько поколений выпускников. Среди них: писатель Гайто Газданов, ученый-астроном Сергей Гапошкин и многие другие, посвятившие свою жизнь служению Болгарии и России. 1 марта 1923 года состоялось торжественное вручение аттестатов 57 первым выпускникам, на котором присутствуют приглашенные шуменцы. Выпускники произносят слова благодарности Болгарии за теплый прием и заботу. Это событие широко освещается в печати (Шуменски вести 1923). В общей сложности в период с 1923 г. по 1934 г. оканчивают гимназию 398 (393) чел., в период 1924-1927 гг. 53 \% выпускников Шуменской русской гимназии получают золотые медали ${ }^{100}$. Впоследствии они продолжают свое обучение в высших учебных заведениях в Болгарии и Европе ${ }^{101}$.

Современная гимназия в Шумене все так же по традиции в народе называется «русской гимназией» и отчасти продолжает традиции своего прототипа. Несмотря на то, что в настоящее время изучение русского языка в ней ограничено одним классом, а программа обучения далека от классической ${ }^{102}$.

На протяжении многих веков русско-болгарские лингвокультурные контакты служат примером уникального взаимообогащения народов. Функционирование русской эмигрантской гимназии в Шумене, одной из шести в Болгарии, является свидетельством прямого лингвокультурного взаимодействия между народами Болгарии и России.

\section{Список литературы:}

1. Ангелов Б. Ст. Съвременници на Паисий. С.: Изд-во на БАН, 1963. Кн. 1. 208 с.

2. Ангелов. Б. Ст. Из старата българска, руска и сръбска литература. Т. I. София, 1958; Т. II. София, 1967. C. 212-213.

\footnotetext{
94 Там же.

${ }^{95}$ ГАРФ. Ф. Р-6089. Бейер. Оп. 1. Д. 16. Л. 23.

${ }^{96}$ ГАРФ. Ф. Р-6089. Оп. 1. Д. 10. Л. 44.

${ }^{97}$ Родионова Н.А. П.К. Дылёв - доктор Швейцер Русского Зарубежья // Россия и современный мир. 2012. № 2. С. 205-212.

${ }^{98}$ Воспоминания выпускников Шуменской гимназии. Архив Н.Г. Пчелинцевой. Т. 1. С. 335.
}

\footnotetext{
99 ДАШ. Ф. 57ОК. ОП. 1. А. е. 13. Л. 63-64, 66.

100 ДАШ. Ф 57ОК. Оп. 1. А. е. 2, 15. Л. 1-23.

101 Зарубежная русская школа: 1920-1924. Париж. С. 52; 65.

102 Долгоруков П. Д. Русская беженская школа. // Русская школа за рубежом. Прага, 1923. № 1. С. 63-82.
} 


\section{Типы обучения}

3. Андрейчин Л. Из историята на нашето езиково строителство. София: Народна просвета, 1986.

4. Бабов К. Найден Геров и его вклад в болгарскую русистику // Болгарская русистика. № 1. София, 1988.

5. Бабов К. Руско-българските езикови контакти и въпросът за типологията на русизмите в българския език // Славянска филология. Т. 15. София, 1978.

6. Бирман М.А., Горяинов А.Н. Российские интеллектуалы-эмигранты в Болгарии 1920-1930 годов // Новая и новейшая история. 2002. № 11. С. 173-193.

7. Бочарова 3.С. Российское зарубежье 1920-1930-х гг. как феномен отечественной истории. М.: АИРОXXI, 2011. $304 \mathrm{c}$.

8. Васильева С.Н. Особенности развития содержания русской школы в условиях эмиграции // Ист.пед. основания стратегии развития отечественного образования / Под ред. З.И. Равкина. М.: ИТГТ, МИО РАО, 1994.

9. Васильева С.Н. Проблемы развития русской школы в условиях эмиграции (1918-1930) // Современные проблемы истории образования и педагогической науки: В 3-х т. / Под ред. 3.И. Равкина. Т. 3. М.: ИТПИМИО, 1994. С. 20-26.

10. Водовозов В. Русские в Болгарии // Всеславянский календарь. Praha: Пламя, 1926.

11. Газданов Г. Собр. соч. в 5-и томах. М.: Эллис Лак, 2009.

12. Газданов Г. Собрание сочинений: В 3-х т. / Сост., подг. текста Л. Диенеша, С. С. Никоненко, Ф. Х. Хадоновой; Вступ. статьи Л. Диенеша и Ст. Никоненко; Послесл. Л. Сыроватко. Комм. Л. Сыроватко, Ст. Никоненко, Л. Диенеша. М.: Согласие, 1996-1999.

13. Гацак В.М. Фольклор и молдавско-русско-украинские исторические связи. М.: Наука, 1975. 232 с.

14. Генов Ц. Славянските комитети в Русия и българското освободително дело (1858-1878). Велико Търново: Изд-во на отечествения фронт, ДП «Д. Найденов», 1986. С.104.

15. Горяинов А.Н. Культурно-просветительных организации русских эмигрантов в Болгарии (до начала 30-х годов ХХ века) // Славяноведение. 1994. № 4.

16. Горяинов А.Н. Русская эмигрантская школа в Болгарии (1920-е гг.). // Педагогика. 1995. № 1.

17. Даскалов Д. Бялата емиграция в България. София: Унив. изд. Св. Климент Охридски, 1997.

18. Даскалов Д. Професионален и културен профил на бялата емиграция в България // Бялата емиграция в България: Материали от науч. конф., София, 23-24 септ. 1999 г. / Ред. кол. Г. Марков и др. София: ИК Гутенберг, 2001.

19. Диенеш JI. Гайто Газданов: Жизнь и творчество. Владикавказ: Изд-во Сев.-Осет. ин-та гуманитарных исслед., 1995. 304 с.

20. Димитров Э. Русская эмиграция в Шумене // Русское зарубежье в Болгарии. История и современность. София: Русский академический союз в Болгарии, 2009.

21. Долгоруков П.Д. Русская беженская школа. // Русская школа за рубежом. Прага, 1923. № 1. С. 63-82.

22. Достян И.С. Българите в руската литература и периодичен печат през първите десетилетия на ХІХ век // Българското Възраждане и Русия / Ред. колегия Д. Косев и др. София: Наука и изкуство, 1981.

23. Дьяконова И.А. Художественное своеобразие романов Гайто Газданова. Автореф. дисс. ... канд. филол. наук. Северодвинск, 2003. 24 с.

24. Земсков В.Б. Писатели цивилизационного «промежутка»: Газданов, Набоков и другие // Гайто Газданов и «незамеченное поколение»: писатель на пересечении традиций и культур. М.: ИНИОН PAH, 2005. С. 7-15.

25. Кабанова Е.В. Школа и учительство русской эмигрантской диаспоры в Европе: 1919-1930 гг. Дисс. ... канд. пед. наук. М., 1998. 145 с.

26. Кананыкина Е.С. Правовой аспект глобализации системы образования стран Латинской Америки // NB: Административное право и практика администрирования. 2013. № 10. С. 89-165. (URL: http:// www.e-notabene.ru/al/article_780.html).

27. Кёсева Ц. Болгария и русская эмиграция: 1920-1950-е годы. М.: Библиотека - фонд «Русское Зарубежье», Русский путь, 2008. 


\section{Педагогика и просвещение 4(12) • 2013}

28. Киржаева В.П. Преподавание русского языка в условиях эмиграции // Образование и педагогическая мысль российского зарубежья, 20-50-е гг. XX в.: Тез. докл. и сообщ. второй всерос. науч. конф. «Образование и пед. Мысль рос. зарубежья, 20-50-е гг. ХХ в.» (Саранск, 16-18 окт. 1997 г.) / Под ред. Е.Г. Осовского. Саранск: МГПИ, 1997.

29. Ковалевский П.Е. Зарубежная Россия: история и культурно-просветительная работа русского зарубежья за полвека. Париж: Librairie des cinq continents, 1971.

30. Кьосева Ц. Руската емиграция в България. София: Междунар. център по проблемите на малцинствата и културните взаимодействия. 2002.

31. Кьосева Ц. Руската емиграция в България. София: Международен център по проблемите на малцинствата и културните взаимодействия, 2002. 591 с.

32. Кьосева Ц. Руската емиграция и българската държава (20-те - 50-те години на XX в) // Бялата емиграция в Българии. Материали от научна кнференция София, 23 и 24 сентября 1999 г. София: Институт по история Българска академия на науките, 2001. С. 51-70.

33. Маринов М., Узунов Х., Караиванов А., Даков Т. Руско-турската освободителна война 1877-1878 гг. София: Държ. изд-во “Народна просвета", 1977. 215 с.

34. Мечев К. Българска фолклорна прослава на Русия от края на XVIII век // Балкански културни връзки през Средновековието. София: Изд-во на БАН, 1982. С. 182-190.

35. Павлова Р. Болгарско-русские и русско-болгарские языковые связи. София: Народна просвета. 1979.

36. Петров А. Александър Петрович Дехтерев. // Бялата емиграция в България. София: ИК Гутенберг, 2001. С. 328-353.

37. Петров А. Материалы по истории русской школы за рубежом // Русская школа за рубежом. № 9. Прага, 1924. С. 92-118.

38. Петрушева Л. Болгария и российская эмиграция (Государственный архив Российской Федерации) // Болгария и российская эмиграция 1920-1945. Каталог выставки. М., 2007. С. 12-13.

39. Петрушева Л. Отцы и дети русской эмиграции // Дети русской эмиграции. М.: Терра, 1997. С. 13-15.

40. Петрушева Л. Русская эмигрантская школа в Европе // Славяноведение. 2009. № 1.

41. Попов К. Из историята на българския книжовен език. София: Изд-во на БАН, 1985.

42. Раев М. Россия за рубежом. История культуры русской эмиграции 1919-1939 / Пер. с англ. М.: Прогресс, Академия, 1994.

43. Родионова Н.А. П.К. Дылёв - доктор Швейцер Русского Зарубежья // Россия и современный мир. 2012. № 2. С. 205-212.

44. Родионова Н.А. Проблемы воспитания детей в эмиграции: труды и дни Шуменской гимназии (19221934) // Исторический журнал: научные исследования. 2011. № 5. С. 60-70.

45. Рупчева Г. Гайто Газданов - ученик в руската гимназия в Шумен // Неуморният търсач: Сборник / Ред. П. Панайотов. Шумен: Аксиос, 2005.

46. Русская школа за рубежом. Книга 24. Прага: Издание Объединения Земских и Городских Деятелей в Чехословакии, 1927.

47. Седова Е.Е. Пути национального воспитания в образовательной системе российской эмиграции 20-30-х гг. ХХ в. // БЕРЕГА: Информационно аналитический сборник о русском зарубежье. Вып. 9. СПб., 2008. С. 30-39.

48. Соковнин П.Н. Данные опыта русских учебных заведений в Болгарии по некоторым вопросам эмигрантской школы // Бюллетень Педагогического Бюро. Прага, 1925. № 7. С. 32-33.

49. Спасов Л. България и СССР 1919-1944 г.: Политико-дипломатически отношения. Велико Търново: Фабер, 2008.

50. Спасов Л. Врангеловата армия в България 1919-1923. София: Унив. изд. Св. Климент Охридски. 1999.

51. Стоянова Е.В. Устаревшие фразеологические единицы русского языка и их болгарские эквиваленты. Дисс. ... канд. филол. наук. М., 2002. 235 с.

52. Стрельцов А.А. Гимназии русского зарубежья // Вопросы образования. 2006. № 2. С. 248-264. 


\section{Типы обучения}

53. Строители и ревнители на родния език. Пантеон / Съставили: Л. Андрейчин и В. Попова. София: Наука и изкуство, 1982.

54. Сухачева В.А. Проблемы образования детей и юношества в Российском Зарубежье (1920-1940 гг.) // Вестник МГПУ. Серия «Педагогика и психология». 2008. № 3 (26). С. 86-96.

55. Толстой Н.И. История и структура славянских литературных языков. М.: Наука, 1988.

56. Хевролина В.М. Руско-турската война 1877-1878 гг. и прогресивна Русия // Българското Възраждане и Русия / Ред. колегия Д. Косев и др. София: Наука и изкуство, 1981. С. 35-57.

57. Цонев Б. История на българския език. Т. 2. София, 1934.

58. Челышев Е.П. Российская эмиграция: 1920-30-е годы: история и современность. М.: Граф-Пресс, 2002.312 c.

59. Шавельский Г.И. Русская школа в Болгарии // Педагогика Российского Зарубежья. М.: Ин-т психологии, 1996.

60. Шавельский Г.И. Русская школа в Болгарии // Труды 5-го съезда русских академических организаций за границей. 4.1. Приложение 2. София, 1932.

61. Шаклеин В.М. Лингвокультурная ситуация и исследование текста. М.: Общество любителей русской словесности, 1997. 180 с.

62. Щербатов А., Криворучкина-Щербатова Л. Право на прошлое. М.: Срет. Монастырь, 2005.

63. Щупленков Н.О., Щупленков О.В. Русский язык эмигрантского зарубежья «первой волны» как средство сохранения национальной самоидентификации // NB: Культуры и искусства. 2014. № 1. С. 31-57. (URL: http://www.e-notabene.ru/ca/article_10686.html).

64. Щупленков О.В. Адаптационные возможности русской эмиграции «первой волны» // Исторические, философские, политические и юридические науки, культурология и искусствоведение. Вопросы теории и практики. Тамбов, 2010. № 2. С. 115-116.

65. Щупленков О.В. Диалектика воспитания в эмиграции первой волны // Перспективы науки. Тамбов, 2010. № 7. С. 84-87.

66. Щупленков О.В. Императивы национальной идеи // NB: Философские исследования. 2013. № 2. C. $122-164$.

67. Щупленков О.В. История молодежного движения в России в современном исследовательском поле // Исторические, философские, политические и юридические науки, культурология и искусствоведение. Вопросы теории и практики. Тамбов, 2012. № 1-2. С. 211-215.

68. Щупленков О.В. Источники финансирования русской школы в эмиграции 1920-1930-х годов // В мире научных открытий. Красноярск, 2011. Т. 15. № 3. С. 146-150.

69. Щупленков О.В. Национальные особенности политического активизма российской молодежи в эмиграции 1920-х-1930-х годов // Исторические, философские, политические и юридические науки, культурология и искусствоведение. Вопросы теории и практики. Тамбов, 2011. № 7-3. С. 220-222.

70. Щупленков О.В. Общественно-политическая самобытность русской эмиграции 1920-1930-х годов // Исторические, философские, политические и юридические науки, культурология и искусствоведение. Вопросы теории и практики. Тамбов, 2011. № 5-4. С. 219-221.

71. Щупленков О.В. Патриотическое воспитание в военном образовании Российского Зарубежья в контексте современного исторического образования школьников // Преподавание истории в школе. 2007. № 10. С. 68.

72. Щупленков О.В., Щупленков Н.О. Идеи солидаризма в концепции построения гражданского общества в России // NB: Проблемы общества и политики. 2013. № 8. С. 72-137.

73. Щупленков О.В., Щупленков Н.О. Национально-культурная идентичность в контексте философской традиции диалога культур // NB: Философские исследования. 2013. № 10. C. 183-244.

\section{References (transliteration):}

1. Angelov. B. St. Iz starata b"lgarska, ruska i sr"'bska literatura. T. I. Sofiya, 1958; T. II. Sofiya, 1967.

2. Angelov B. St. S"vremennitsi na Paisii. S.: Izd-vo na BAN, 1963. Kn. 1. 208 s. 


\section{Педагогика и просвещение 4(12) • 2013}

3. Andreichin L. Iz istoriyata na nasheto ezikovo stroitelstvo. Sofiya: Narodna prosveta, 1986.

4. Babov K. Naiden Gerov i ego vklad v bolgarskuyu rusistiku // Bolgarskaya rusistika. Sofiya, 1988. № 1.

5. Babov K. Rusko-b"Igarskite ezikovi kontakti i v"pros"t za tipologiyata na rusizmite v b"lgarskiya ezik // Slavyanska filologiya. T. 15. Sofiya, 1978. S. 40.

6. Birman M.A., Goryainov A.N. Rossiiskie intellektualy-emigranty v Bolgarii 1920-1930 godov // Novaya i noveishaya istoriya. 2002. № 11. S. 173-193.

7. Bocharova Z.S. Rossiiskoe zarubezh'e 1920-1930-kh gg. kak fenomen otechestvennoi istorii. M.: AIRO-XXI, 2011. $304 \mathrm{~s}$.

8. Vasil'eva S.N. Osobennosti razvitiya soderzhaniya russkoi shkoly v usloviyakh emigratsii // Ist.-ped. osnovaniya strategii razvitiya otechestvennogo obrazovaniya / Pod red. Z.I. Ravkina. M.: ITGT, MIO RAO, 1994.

9. Vasil'eva S.N. Problemy razvitiya russkoi shkoly v usloviyakh emigratsii (1918-1930) // Sovremennye problemy istorii obrazovaniya i pedagogicheskoi nauki: V 3-kh t. / Pod red. Z.I. Ravkina. T. 3. M.: ITPIMIO, 1994. S. 20-26.

10. Vodovozov V. Russkie v Bolgarii // Vseslavyanskii kalendar'. Praha: Plamya, 1926.

11. Gazdanov G. Sobr. soch. v 5-kh t. M.: Ellis Lak. 2009.

12. Gazdanov G. Sobranie sochinenii: V 3 t. / Sost., podg. teksta L. Dienesha, S.S. Nikonenko, F.Kh. Khadonovoi; Vstup. stat'i L. Dienesha i St. Nikonenko; Poslesl. L. Syrovatko. Komm. L. Syrovatko, St. Nikonenko, L. Dienesha. M.: Soglasie, 1996-1999.

13. Gatsak V.M. Fol'klor i moldavsko-russko-ukrainskie istoricheskie svyazi. M.: Nauka, 1975. $232 \mathrm{~s}$.

14. Genov Ts. Slavyanskite komiteti v Rusiya i b"lgarskoto osvoboditelno delo (1858-1878). Veliko T"rnovo: Izd-vo na otechestveniya front, DP «D. Naidenov», 1986.

15. Goryainov A.N. Kul'turno-prosvetitel'nykh organizatsii russkikh emigrantov v Bolgarii (do nachala 30-kh godov KhKh veka) // Slavyanovedenie. 1994. № 4.

16. Goryainov A.N. Russkaya emigrantskaya shkola v Bolgarii (1920-e gg.) // Pedagogika. 1995. № 1.

17. Daskalov D. Byalata emigratsiya v B"lgariya. Sofiya: Univ. izd. Sv. Kliment Okhridski, 1997.

18. Daskalov D. Profesionalen i kulturen profil na byalata emigratsiya v B"lgariya // Byalata emigratsiya v B"lgariya: Materiali ot nauch. konf., Sofiya, 23-24 sept. 1999 g. / Red. kol. G. Markov i dr. Sofiya: IK Gutenberg, 2001. S. 71-78.

19. Dienesh JI. Gaito Gazdanov: Zhizn' i tvorchestvo. Vladikavkaz: Izd-vo Sev.-Oset. in-ta gumanitarnykh issled., 1995. $304 \mathrm{~s}$.

20. Dimitrov E. Russkaya emigratsiya v Shumene // Russkoe zarubezh'e v Bolgarii. Istoriya i sovremennost'. Sofiya: Russkii akademicheskii soyuz v Bolgarii, 2009.

21. Dolgorukov P.D. Russkaya bezhenskaya shkola. // Russkaya shkola za rubezhom. Praga, 1923. № 1. S. 63-82.

22. D’yakonova I.A. Khudozhestvennoe svoeobrazie romanov Gaito Gazda-nova. Avtoref. diss. ... kand. filol. nauk. Severodvinsk, 2003. $24 \mathrm{~s}$.

23. Dostyan I.S. B"lgarite v ruskata literatura i periodichen pechat prez p"rvite desetiletiya na XIX vek // B"'lgarskoto V"zrazhdane i Rusiya / Red. kolegiya D. Kosev i dr. Sofiya: Nauka i izkustvo. 1981.

24. Zemskov V.B. Pisateli tsivilizatsionnogo «promezhutka»: Gazdanov, Nabokov i drugie // Gaito Gazdanov i «nezamechennoe pokolenie»: pisatel' na peresechenii traditsii i kul'tur. M.: INION RAN, 2005. S. 7-15.

25. Kabanova E.V. Shkola i uchitel'stvo russkoi emigrantskoi diaspory v Evrope: 1919-1930 gg. Diss. ... kand. ped. nauk. M., 1998. $145 \mathrm{~s}$.

26. Kananykina E.S. Pravovoi aspekt globalizatsii sistemy obrazovaniya stran Latinskoi Ameriki // NB: Administrativnoe pravo i praktika administrirovaniya. 2013. № 10. S. 89-165. (URL: http://www.e-notabene.ru/al/article_780.html).

27. Keseva Ts. Bolgariya i russkaya emigratsiya: 1920-1950-e gody. M.: Biblioteka — fond «Russkoe Zarubezh'e», Russkii put', 2008.

28. Kirzhaeva V.P. Prepodavanie russkogo yazyka v usloviyakh emigratsii // Obrazovanie i pedagogicheskaya mysl' rossiiskogo zarubezh'ya, 20-50-e gg. XX v.: Tez. dokl. i soobshch. vtoroi vseros. nauch. konf. 


\section{Типы обучения}

«Obrazovanie i ped. Mysl’ ros. zarubezh'ya, 20-50-e gg. XX v.» (Saransk, 16-18 okt. 1997 g.) / Pod red. E.G. Osovskogo. Saransk: MGPI, 1997.

29. Kovalevskii P.E. Zarubezhnaya Rossiya: istoriya i kul'turno-prosvetitel'naya rabota russkogo zarubezh'ya za polveka. Parizh: Librairie des cinq continents, 1971.

30. K'oseva Ts. Ruskata emigratsiya v B"lgariya. Sofiya: Mezhdunaroden tsent"r po problemite na maltsinstvata i kulturnite vzaimodeistviya, 2002. $591 \mathrm{~s}$.

31. K'oseva Ts. Ruskata emigratsiya i b"lgarskata d"rzhava (20-te - 50-te godini na KhKh v) // Byalata emigratsiya v B"Igarii. Materiali ot nauchna knferentsiya Sofiya, 23 i 24 sentyabrya 1999 g. Sofiya: Institut po istoriya B"lgarska akademiya na naukite, 2001. S. 51-70.

32. K'oseva Ts. Ruskata emigratsiya v B"lgariya. Sofiya: Mezhdunar. tsent"r po problemite na maltsinstvata i kulturnite vzaimodeistviya, 2002.

33. Marinov M., Uzunov X., Karaivanov A., Dakov T. Rusko-turskata osvoboditelna voina 1877-1878 gg. Sofiya: D"rzh. izd-vo "Narodna prosveta", 1977. $215 \mathrm{~s}$.

34. Mechev K. B"'lgarska folklorna proslava na Rusiya ot kraya na XVIII vek // Balkanski kulturni vr"zki prez Srednovekovieto. Sofiya: Izd-vo na BAN, 1982. S. 182-190.

35. Pavlova R. Bolgarsko-russkie i russko-bolgarskie yazykovye svyazi. Sofiya: Narodna prosveta, 1979.

36. Petrov A. Aleksand"r Petrovich Dekhterev // Byalata emigratsiya v B"'lgariya. Sofiya: IK Gutenberg. 2001. S. 328-353.

37. Petrov A. Materialy po istorii russkoi shkoly za rubezhom // Russkaya shkola za rubezhom. Praga, 1924. № 9. S. 92-118.

38. Petrusheva L. Bolgariya i rossiiskaya emigratsiya (Gosudarstvennyi arkhiv Rossiiskoi Federatsii) // Bolgariya i rossiiskaya emigratsiya 1920-1945. Katalog vystavki. M., 2007. S. 12-13.

39. Petrusheva L. Ottsy i deti russkoi emigratsii. // Deti russkoi emigratsii. M.: Terra, 1997. S. 13-15.

40. Petrusheva L. Russkaya emigrantskaya shkola v Evrope // Slavyanovedenie. 2009. № 1.

41. Popov K. Iz istoriyata na b"lgarskiya knizhoven ezik. Sofiya: Izd-vo na BAN, 1985.

42. Raev M. Rossiya za rubezhom. Istoriya kul'tury russkoi emigratsii 1919-1939 / Per. s angl. M.: Progress, Akademiya, 1994.

43. Rodionova N.A. P.K. Dylev - doktor Shveitser Russkogo Zarubezh'ya // Rossiya i sovremennyi mir. 2012. № 2. S. 205-212.

44. Rodionova N.A. Problemy vospitaniya detei v emigratsii: trudy i dni Shumenskoi gimnazii (1922-1934) // Istoricheskii zhurnal: nauchnye issledovaniya. 2011. № 5. S. 60-70.

45. Rupcheva G. Gaito Gazdanov — uchenik v ruskata gimnaziya v Shumen // Neumorniyat t"rsach: Sbornik / Red. P. Panaiotov. Shumen: Aksios, 2005.

46. Russkaya shkola za rubezhom. Kniga 24. Praga: Izdanie Ob"edineniya Zemskikh i Gorodskikh Deyatelei v Chekhoslovakii, 1927. S. 702-706.

47. Sedova E.E. Puti natsional'nogo vospitaniya v obrazovatel'noi sisteme rossiiskoi emigratsii 20-30-kh gg. XX v. // BEREGA: Informatsionno analiticheskii sbornik o russkom zarubezh'e. Vyp. 9. SPb., 2008. S. 30-39.

48. Sokovnin P.N. Dannye opyta russkikh uchebnykh zavedenii v Bolgarii po nekotorym voprosam emigrantskoi shkoly // Byulleten’ Pedagogicheskogo Byuro. Praga, 1925. № 7. S. 32-33.

49. Spasov L. B"lgariya i SSSR 1919-1944 g.: Politiko-diplomaticheski otnosheniya. Veliko T"rnovo: Faber, 2008.

50. Spasov L. Vrangelovata armiya v B"lgariya 1919-1923. Sofiya: Univ. izd. Sv. Kliment Okhridski, 1999.

51. Stoyanova E.V. Ustarevshie frazeologicheskie edinitsy russkogo yazyka i ikh bolgarskie ekvivalenty. Diss. ... kand. filol. nauk. M., 2002. $235 \mathrm{~s}$.

52. Strel'tsov A.A. Gimnazii russkogo zarubezh'ya // Voprosy obrazovaniya. 2006. № 2. S. 248-264.

53. Stroiteli i revniteli na rodniya ezik. Panteon / S"stavili: L. Andreichin i V. Popova. Sofiya: Nauka i izkustvo, 1982.

54. Sukhacheva V.A. Problemy obrazovaniya detei i yunoshestva v Rossiiskom Zarubezh'e (1920-1940 gg.) // Vestnik MGPU. Seriya «Pedagogika i psikhologiya». 2008. № 3 (26). S. 86-96.

55. Tolstoi N.I. Istoriya i struktura slavyanskikh literaturnykh yazykov. M.: Nauka, 1988. 


\section{Педагогика и просвещение 4(12) • 2013}

56. Khevrolina V.M. Rusko-turskata voina 1877-1878 gg. i progresivna Rusiya // B"'lgarskoto V"zrazhdane i Rusiya / Red. kolegiya D. Kosev i dr. Sofiya: Nauka i izkustvo, 1981. S. 35-57.

57. Tsonev B. Istoriya na b"'lgarskiya ezik. T. 2. Sofiya, 1934.

58. Chelyshev E.P. Rossiiskaya emigratsiya: 1920-30-e gody: istoriya i sovremennost'. M.: Graf-Press, 2002. $312 \mathrm{~s}$.

59. Shavel'skii G.I. Russkaya shkola v Bolgarii // Pedagogika Rossiiskogo Zarubezh'ya. M.: In-t psikhologii, 1996.

60. Shavel'skii G.I. Russkaya shkola v Bolgarii // Trudy 5-go s"ezda russkikh akademicheskikh organizatsii za granitsei. 4.1. Prilozhenie 2. Sofiya, 1932.

61. Shaklein V.M. Lingvokul'turnaya situatsiya i issledovanie teksta. M.: Obshchestvo lyubitelei russkoi slovesnosti, 1997. $180 \mathrm{~s}$.

62. Shcherbatov A., Krivoruchkina-Shcherbatova L. Pravo na proshloe. M.: Sret. Monastyr', 2005.

63. Shchuplenkov N.O., Shchuplenkov O.V. Russkii yazyk emigrantskogo zarubezh'ya «pervoi volny» kak sredstvo sokhraneniya natsional'noi samoidentifikatsii // NB: Kul'tury i iskusstva. 2014. № 1. S. 31-57. (URL: http:// www.e-notabene.ru/ca/article_10686.html).

64. Shchuplenkov O.V. Adaptatsionnye vozmozhnosti russkoi emigratsii «pervoi volny» // Istoricheskie, filosofskie, politicheskie i yuridicheskie nauki, kul'turologiya i iskusstvovedenie. Voprosy teorii i praktiki. Tambov, 2010. № 2. S. 115-116.

65. Shchuplenkov O.V. Dialektika vospitaniya v emigratsii pervoi volny // Perspektivy nauki. Tambov, 2010. № 7. S. 84-87.

66. Shchuplenkov O.V. Imperativy natsional'noi idei // NB: Filosofskie issledovaniya. 2013. № 2. S. 122-164.

67. Shchuplenkov O.V. Istochniki finansirovaniya russkoi shkoly v emigratsii 1920-1930-kh godov // V mire nauchnykh otkrytii. Krasnoyarsk, 2011. T. 15. № 3. S. 146-150.

68. Shchuplenkov O.V. Istoriya molodezhnogo dvizheniya v Rossii v sovremennom issledovatel'skom pole // Istoricheskie, filosofskie, politicheskie i yuridicheskie nauki, kul'turologiya i iskusstvovedenie. Voprosy teorii i praktiki. Tambov, 2012. № 1-2. S. 211-215.

69. Shchuplenkov O.V. Natsional'nye osobennosti politicheskogo aktivizma rossiiskoi molodezhi v emigratsii 1920-kh-1930-kh godov // Istoricheskie, filosofskie, politicheskie i yuridicheskie nauki, kul'turologiya i iskusstvovedenie. Voprosy teorii i praktiki. Tambov, 2011. № 7-3. S. 220-222.

70. Shchuplenkov O.V. Obshchestvenno-politicheskaya samobytnost' russkoi emigratsii 1920-1930-kh godov // Istoricheskie, filosofskie, politicheskie i yuridicheskie nauki, kul'turologiya i iskusstvovedenie. Voprosy teorii i praktiki. Tambov, 2011. № 5-4. S. 219-221.

71. Shchuplenkov O.V. Patrioticheskoe vospitanie v voennom obrazovanii Rossiiskogo Zarubezh'ya v kontekste sovremennogo istoricheskogo obrazovaniya shkol'nikov // Prepodavanie istorii v shkole. 2007. № 10.

72. Shchuplenkov O.V., Shchuplenkov N.O. Idei solidarizma v kontseptsii postroeniya grazhdanskogo obshchestva v Rossii // NB: Problemy obshchestva i politiki. 2013. № 8. S. 72-137.

73. Shchuplenkov O.V., Shchuplenkov N.O. Natsional'no-kul'turnaya identichnost'v kontekste filosofskoi traditsii dialoga kul'tur // NB: Filosofskie issledovaniya. 2013. № 10. S. 183-244. 